\title{
Factors Affecting Thaxtomin A Production by Streptomyces scabies in Egypt
}

\section{M.A. El-Sheikh*; S.A. El-Kazzaz**;} Eman El-Argawy* and M.H. Ghozlan*

* Plant Pathol. Dept., Fac. of Agric., Damanhour Univ.

** Plant Pathol. Dept., Fac. of Agric., Alexandria Univ.

\begin{abstract}
Twenty isolates of Streptomyces scabies were isolated from scab lesions on potato tubers collected from three different regions in Behera Governorate during the 2009-2010 growing season. The isolates of S. scabies recovered were totally monomorphic for the morphological and the biochemical characteristics investigated. All isolates were non motile, gram positive, exhibited grey colonies, spiral spore chain and were melanin producers. Meantime the isolates showed positive reaction for catalase activity, starch hydrolysis, casein hydrolysis and gelatine liquefaction. Also, all isolates were tolerant and exhibited growth at $\mathrm{NaCl} 5,6 \& 7 \%$ and at $20,25 \& 30^{\circ} \mathrm{C}$ at $\mathrm{pH} 7 \& 9$. None of the tested isolates were able to grow at $\mathrm{pH} 5$. More variations, however, were revealed for the pathogenicity of twenty isolates. Five out of twenty investigated isolates were found to be highly virulent. The rest of tested isolates were moderately virulent. Spunta was the most tolerant potato cultivar, while cvs. Mondial and Hermis were more susceptible. The highly virulent $S$. scabies (isolate ST5) was a highly producer of Thaxtomin A, while the moderately virulent isolate (ST10) was poorly toxin producer $(1.26 \mathrm{mg} / \mathrm{ml}$ medium). The optimal conditions for Thaxtomin A production were $28^{\circ} \mathrm{C}, \mathrm{pH} 8$ and $1 \%$ cellobiose in medium. The amino acids, i.e. tryptophan, phenylalanine and tyrosine exhibited an in vitro inhibitory effect on the toxin production in the amended oatmeal bran broth medium with highest inhibitory effect was recorded for tryptophan.
\end{abstract}

Keywords: Common scab, phytotoxin, potato, Streptomyces scabies and Thaxtomin A.

Streptomyces spp. are group of filamentous Gram-positive saprophytic bacteria found in soil. These organisms produce a great variety of antibiotics and other secondary metabolites and few species of the genus are plant pathogens amongst them, S. scabies the causal agent of the potato scab (Lambert and Loria, 1989 and Faucher et al., 1992). Common scab of potato occurs in all potato growing areas of the world and is induced by other species of the genus Streptomyces (Archuleta and Easton, 1981 and Loria et al., 2003). Thaxtomin A, as a phytotoxin, capable of inducing scab-like lesions on immature potato tubers was characterized as a unique 4- nitroindol-1-3 yl containing 2.5 dioxopiprazines (King et al., 1989 and Lawerence et al., 1990). A correlation was observed between the pathogenicity of S. scabies isolates and their ability to produce the phytotoxin Thaxtomin A (King et al., 1989 and Lerat et al., 2009). In addition, Delserone et al. (1991) found a positive correlation between $S$. scabies resistance and Thaxtomin sensitivity in different 
potato cultivars. According to Kim et al. (1998), crude extracts of pathogenic S. turgidiscabies isolates produced a necrotic reaction on potato slices $24 \mathrm{~h}$ after application and increased in severity in the following days. However, necrosis was not observed when crude extracts of non pathogenic strains were applied onto tuber slices. Presence of Thaxtomin A from crude extracts of pathogenic S. turgidiscabies was identified by thin layer chromatography and high performance liquid chromatography. The pathogenicity of Streptomyces spp. was evaluated using potato berries where pathogenic strains caused necrotic lesions (Shigeo et al., 2006) and on potato slices (Natsume et al., 2005), while non pathogenic strains showed no symptoms. Thaxtomin A production varied generally among different media and among different S. scabies strains (Beauséjour et al., 1999 and Wach et al., 2007). Natsume et al. (2001) found that the Thaxtomin A production decreased at $\mathrm{pH} 7.5$ and $15^{\circ} \mathrm{C}$ and the aerial mycelium formation was greater in case of higher $\mathrm{pH}, \mathrm{Ca}^{+2}$ concentration and temperature. In addition, Lauzier et al. (2002) reported that tryptophan had an important inhibitory effect on the toxin biosynthesis.

Therefore, the present study was conducted to identify the role of Thaxtomin A in virulence of Streptomyces scabies, the causal agent of common scab of potato and to reveal the factors affecting its production.

\section{Materials and Methods}

\section{1- Isolation and characterization of bacterial isolates associated with common scab} symptoms:

During the 2009-2010 growing season, potato tubers showing common scab symptoms were collected from different fields in Behera Governorate. Bacterial isolates associated with common scab were isolated from potato tubers as described by Loria and Davis (1989). Whole tubers were surface-disinfested for 10 minutes in $0.6 \%$ sodium hypochlorite and rinsed twice for 10 minutes in sterile distilled water (SDW). The corky layer of each lesion was removed aseptically and about $5 \mathrm{~mm}$ of straw-coloured tissue directly underneath the lesion was removed and triturated in $5 \mathrm{ml}$ SDW with a pestle and mortar. After approximately 10 minutes, a drop of the suspension was plated on yeast malt extract (YME-ISP medium 2). Plates were incubated at $30^{\circ} \mathrm{C}$ for $10-14$ days and single colonies were identified according to Shirling and Gottlieb (1966). Cultures were maintained on YME slants at $4^{\circ} \mathrm{C}$ for further studies.

Characteristics of all the recovered bacterial isolates, i.e. colony colour, spore chain morphology, production of melanin and production of diffusible pigments, were investigated according to Shirling and Gottlieb (1966) in three Petri dishes 7 and 14 days at $28^{\circ} \mathrm{C}$. Spore chain morphology of mature colonies was investigated at 100x magnification. Presence and absence of melanin was recorded 7 days after growth on two types of slants of peptone yeast extract iron agar and tyrosine agar according to Shirling and Gottlieb (1966). Motility, Gram staining, catalase activity, starch hydrolysis, casein hydrolysis, gelatine liquefaction, growth tolerance to different $\mathrm{NaCl}$ concentrations $5,6 \& 7 \%$, growth at 20,25 and $30^{\circ} \mathrm{C}$ as well as growth at different $\mathrm{pH}(5,7$ and 9$)$ were investigated as described by Bergy's manual of determinative bacteriology (Bergy, 2004). 


\section{2- Pathogenicity tests and varietal reaction:}

Certified tubers of potato cultivars Spunta, Hermis, and Mondial friendly obtained from Kafr El-Zayat international potato association were planted in a greenhouse in $30 \mathrm{~cm}$-diameter pots containing peat moss and vermiculite medium. Forty five days after planting, plants were harvested to obtain the mini tubers. Potato mini tubers were harvested and surface-disinfested for $10 \mathrm{~min}$. in $0.6 \%$ sodium hypochlorite and rinsed twice for $10 \mathrm{~min}$. in sterile distilled water (SDW) and left to dry. Bacterial inocula were prepared as described by Leiner et al. (1996). Spores of Streptomyces isolates produced on colony surfaces were scrapped free and used to inoculate $50 \mathrm{ml}$ volumes of tryptone yeast broth. These cultures were incubated for 8 days on a rotary shaker at $160 \mathrm{rpm}$. The inocula were added to autoclaved vermiculite ( $50 \mathrm{ml}$ of tryptone yeast broth to 1.51 . of vermiculite). The vermiculite inocula were added to twenty potato mini tubers of each cultivar in small plastic bags, incubated for seven days and shaken vigorously several times during that period. The control treatment was an uninoculated potato mini tuber. Mini tubers were removed from vermiculite, rinsed in water and left to dry. Percent surface area covered with necrotic lesions was estimated and individual scab index was calculated as follows: $0=$ no scab, $1=1 \%, 2=10 \%, 3=25 \%, 4=50 \%, 5=75 \%$ and $6>75 \%$ of the tuber surface covered. The average scab index for each isolate was calculated according to Leiner et al. (1996) as follows:

Average scab index $=\frac{\Sigma(\text { individual scab index } X \text { tubers per index })}{\text { Total number of tubers }}, 0$

Then, isolates were classified as highly virulent, i.e. average scab index $\geq 70 \%$, moderately virulent, i.e. average scab index $<70 \%-\geq 50 \%$ and weakly virulent, i.e. average scab index $<50 \%$.

\section{Toxin studies:}

\subsection{Toxin extraction and quantification:}

The most highly virulent bacterial isolate as well as one of the most weakly virulent ones, identified in the pathogenicity test, were chosen for comparative studies for toxin production. One hundred and fifty micro litres spore suspension of the two tested isolates were mixed with $50 \mathrm{ml}$ oatmeal bran broth, and incubated at $28^{\circ} \mathrm{C}$ with shaking (200 rpm) for eight days. After centrifugation (300 rpm, $\left.20 \mathrm{~min}\right)$, toxin was extracted from supernatants using an equal volume of ethyl acetate. The extract was concentrated by evaporation at $50^{\circ} \mathrm{C}$ by rotary evaporator, and the remaining was redissolved in ethyl acetate. Toxins were then analyzed according to Babcock et al. (1993). The toxins were separated by thin-layer chromatography on glass plates recoated with $0.25 \mathrm{~mm}$ of silica gel 60 , using chloroform/methanol $(9: 1)$ as migration solvents, and the yellow bands $(\mathrm{R} f=0.27)$ indicated the purified toxin. Bands were co migrated with authentic Thaxtomin kindly supplied by R.R. King, Fredericton, Canada. Thaxtomin was quantified by UV and VIS spectroscopic analysis, which was performed with a Deuterium UV/VIS 21 D spectrophotometer using the absorption coefficient determined by King et al. (1992). Thaxtomin was 
eluted with methanol and monitored as absorbance $380 \mathrm{~nm}$.Toxin in crude extracts from the two tested isolates were identified by high performance liquid chromatography (HPLC) using a Shimadzu 10A system with a symmetry C18 column (Waters, 3.9'150 mm). Thaxtomin A was eluted with a $25 \%$ acetonitrile during $20 \mathrm{~min}$ and monitored at $380 \mathrm{~nm}$ (King and Calhoun, 2009).

\subsection{Duration and rate of Thaxtomin A production:}

A highly toxin producer isolate was chosen to investigate factors affecting Thaxtomin A production. The oatmeal bran broth medium was prepared according to Shirling and Gottlieb (1966). Flasks $(150 \mathrm{ml})$ with medium were inoculated with the tested S. scabies isolates ST5. Filtrates were extracted after 2,4,6,8 and 10 days of inoculation, and the amounts of Thaxtomin A were determined as previously described according to King et al. (1992).

\subsection{The effect of temperature:}

The tested isolate grown on oatmeal bran broth medium was incubated at 25,28 and $30^{\circ} \mathrm{C}$ for eight days to investigate the effect of temperature on toxin production. Five Erlenmeyer flasks were prepared for each temperature degree and the amount of toxin in each extract was quantified according to Babcock et al. (1993)

\subsection{The effect of $\mathrm{pH}$ :}

The effect of $\mathrm{pH}$ on toxin production by the tested isolate was investigated by quantifying the toxin production at different $\mathrm{pH}$ values ranging from 7 to 9 . The $\mathrm{pH}$ values were adjusted by using $0.1 \mathrm{~N} 1 \mathrm{ml}$ of $\mathrm{NaOH}$. Five Erlenmeyer flasks were prepared for each value and the amounts of toxin were quantified according to Babcock et al. (1993) as abovementioned.

\subsection{The effect of certain carbohydrates:}

The tested isolate was inoculated to oatmeal bran broth medium supplemented with $0,0.1,0.3,0.5,0.7$ and $1 \%(\mathrm{w} / \mathrm{v})$ of the tested sugars, i.e. glucose, fructose, and cellobiose, in $150 \mathrm{ml}$ Erlenmeyer flasks. Five replicate flasks for each carbohydrate concentration were prepared. Flasks free of sugars served as a control. Flasks were incubated for 5 days at $28^{\circ} \mathrm{C}$ and the amount of toxin in each treatment was quantified according to Babcock et al. (1993) as abovementioned.

\subsection{The effect of amino acids on Thaxtomin A production:}

Three amino acids, i.e. tyrosine, tryptophan and phenylalanine were tested and added as $2 \%(\mathrm{w} / \mathrm{v})$ to $50 \mathrm{ml}$ of oatmeal bran broth medium mixed with $150 \mu \mathrm{l}$ spore suspension of the tested isolate. Five replicate flasks were performed for each amino acid. Oatmeal bran broth medium without amino acid served as a control. All flasks were incubated for eight days at $28^{\circ} \mathrm{C}$ and the amounts of toxin were determined as abovementioned.

\section{Statistical analysis:}

The obtained data were statistically analysed using SAS program (Anonymous, 2000). Least significant differences test (LSD) was used to compare means and to rank isolates. 


\section{R e s u l t s}

1. Characteristics of bacterial isolates associated with common scab of potato:

Twenty isolates of Streptomyces scabies were recovered from potato tubers showed common scab symptoms, collected from different fields in Behera Governorate during the 2009-2010 growing season. All isolates were investigated for their different biochemical and morphological characteristics. All isolates showed grey colonies, with spiral spore chain, gram positive and were non motile. Also, all isolates exhibited positive reaction for catalase activity, gelatine liquefaction, hydrolysis of starch, growth on $\mathrm{pH}$ (7 and 9), growth on $\mathrm{NaCl}(5,6$ and 7\%), growth at 20,25 and $30^{\circ} \mathrm{C}$ of temperature, and the melanin production. However, the isolates did not produce any diffusible pigments (Figs. $1 \& 2$ and Table 1).

Table 1. Morphological and biochemical characteristics of Streptomyces scabies isolates recovered from potato tubers collected from different fields in Behera Governorate during the 2009-2010 growing season

\begin{tabular}{|c|c|c|c|c|c|c|c|c|c|c|c|c|c|c|c|c|c|c|c|c|}
\hline Characteristics & $\begin{array}{c}\text { ST } \\
1\end{array}$ & $\begin{array}{c}\text { ST } \\
2\end{array}$ & $\begin{array}{c}\text { ST } \\
3\end{array}$ & $\begin{array}{c}\text { ST } \\
4\end{array}$ & $\begin{array}{c}\mathrm{ST} \\
5\end{array}$ & \begin{tabular}{c|} 
ST \\
5
\end{tabular} & \begin{tabular}{c|} 
ST \\
7
\end{tabular} & $\begin{array}{c}\text { ST } \\
8\end{array}$ & \begin{tabular}{|c|} 
ST \\
8
\end{tabular} & $\begin{array}{l}\text { ST } \\
10\end{array}$ & $\begin{array}{l}\text { ST } \\
11\end{array}$ & $\begin{array}{l}\text { ST } \\
12\end{array}$ & $\begin{array}{l}\text { ST } \\
13\end{array}$ & $\begin{array}{l}\text { ST } \\
14\end{array}$ & $\begin{array}{l}\text { ST } \\
15\end{array}$ & \begin{tabular}{l|} 
ST \\
16
\end{tabular} & $\begin{array}{l}\text { ST } \\
17\end{array}$ & \begin{tabular}{l|} 
ST \\
18
\end{tabular} & $\begin{array}{l}\text { ST } \\
19\end{array}$ & $\begin{array}{l}\text { ST } \\
20\end{array}$ \\
\hline Colony color & gray & gay & gray & gaty & gray & gray & gray & gray & gray & gray & gxay & gray & gxay & gray & gray & grey & gray & gray & gray & grey \\
\hline Spore chain & $s$ & $s$ & $s$ & $s$ & $s$ & $s$ & $s$ & $s$ & S & $S$ & $s$ & $s$ & $s$ & S & $s$ & S & $s$ & S & $s$ & $S$ \\
\hline Melanin production & + & + & + & + & + & + & + & + & + & + & + & + & + & + & + & + & + & + & + & + \\
\hline Diffusible pigment & + & + & + & + & + & + & + & + & + & + & + & + & + & + & + & + & + & + & + & + \\
\hline Motility & . & $\cdot$ & - & . & . & - & . & . & . & . & - & - & . & . & - & . & - & . & - & . \\
\hline Gram staining & + & + & + & + & + & + & + & + & + & + & + & + & + & + & + & + & + & + & + & + \\
\hline Catalase activity & + & + & + & + & + & + & + & + & + & + & + & + & + & + & + & + & + & + & + & + \\
\hline Starch hỵdrolỵsis & + & + & + & + & + & + & + & + & + & + & + & + & + & + & + & + & + & + & + & + \\
\hline Casein hydrolysis & + & + & + & + & + & + & + & + & + & + & + & + & + & + & + & + & + & + & + & + \\
\hline Gelatin liquefaction & + & + & + & + & + & + & + & + & + & + & + & + & + & + & + & + & + & + & + & + \\
\hline $\begin{array}{c}\text { Tolerance to } \mathrm{Nacl} \\
5 \% \\
\end{array}$ & + & + & + & + & + & + & + & + & + & + & + & + & + & + & + & + & + & + & + & + \\
\hline $6 \%$ & + & + & + & + & + & + & + & + & + & + & + & + & + & + & + & + & + & + & + & + \\
\hline $7 \%$ & + & + & + & + & + & + & + & + & + & + & + & + & + & + & + & + & + & + & + & + \\
\hline Growth at $20^{\circ} \mathrm{C}$ & + & + & + & + & + & + & + & + & + & + & + & + & + & + & + & + & + & + & + & + \\
\hline $25 \mathrm{C}^{\circ}$ & + & + & + & + & + & + & + & + & + & + & + & + & + & + & + & + & + & + & + & + \\
\hline $30^{\circ} \mathrm{C}$ & + & + & + & + & + & + & + & + & + & + & + & + & + & + & + & + & + & + & + & + \\
\hline Growth at pH 5 & . & . & - & . & . & . & . & . & . & . &. & - &. & . & - & . & . & . & . &. \\
\hline 7 & + & + & + & + & + & + & + & + & + & + & + & + & + & + & + & + & + & + & + & + \\
\hline 9 & + & + & + & + & + & + & + & + & + & + & + & + & + & + & + & + & + & + & + & + \\
\hline
\end{tabular}

$+=$ Positive reaction; $-=$ Negative reaction; $\mathrm{S}=$ Spiral spore chain. Colony morphology was recorded on yeast malt extract medium 7 days after incubation at $30^{\circ} \mathrm{C}$. Melanin production was investigated on peptone yeast extract iron agar medium 14 days after incubation at $30^{\circ} \mathrm{C}$. Spore chain morphology was tested on yeast malt extract medium 7 days after incubation at $30^{\circ} \mathrm{C}$ by light microscope on 100x. Presence or absences of diffusible pigments were investigated on yeast malt medium 14 days after of incubation at $30^{\circ} \mathrm{C}$. 


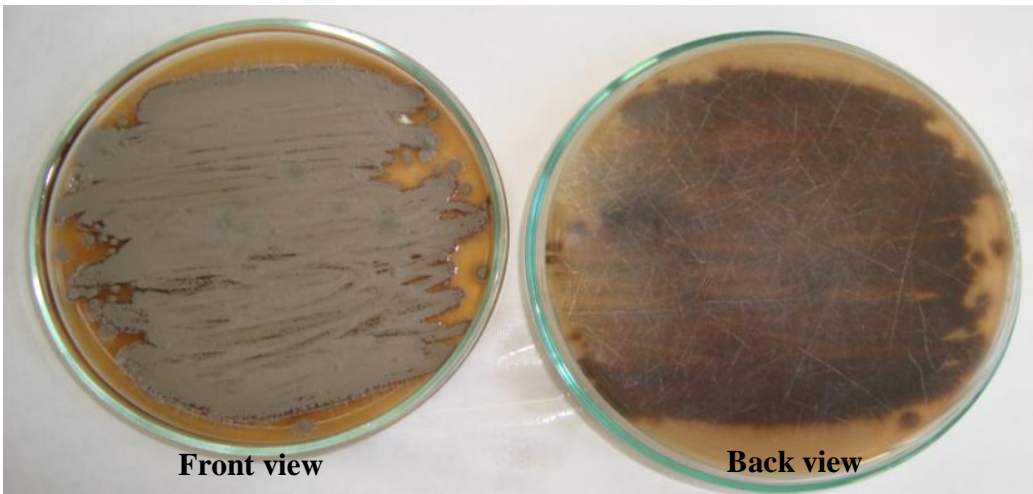

Fig. 1. Culture characteristics of Streptomyces scabies (isolate, ST5) showing grey colonies with melanin pigment production.

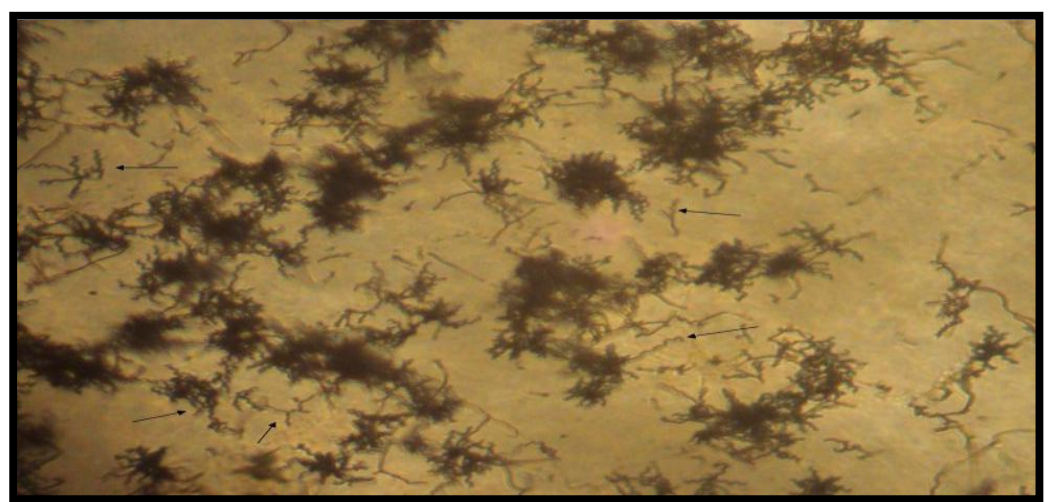

Fig. 2. Streptomyces scabies (isolate ST5) showing the phenotype of spiral spore chain, arrows indicate the spiral shape of sporophore.

\section{Pathogenicity tests and varietal reaction:}

Data in Table (2) show that there was a considerable variation between the tested isolates for their virulence on the potato cultivar tested. Five isolates out of the twenty isolates investigated were characterized as highly virulent, i.e. scab index $\geq 70 \%$. The rest fifteen isolates, however, were moderately virulent, i.e. scab index $<70-\geq 50 \%$. No isolates were characterized as weakly virulent, i.e. scab lesions index $<50 \%$. On the other hand, tested potato cultivars, i.e. Hermis, Mondial, and Spunta, were all susceptible to common scab lesions to different degrees. Cv. Spunta, however, was the most relatively tolerant of the three tested cultivars and exhibited $53.37 \%$ common scab index. Meanwhile, cvs. Hermis and Mondial were more susceptible and showed 73.73 and $63.28 \%$ scab indices, respectively (Table 2). 
Table 2: Scab index of the recovered Streptomyces scabies isolates on mini tubers of three cultivars of potato under greenhouse conditions

\begin{tabular}{|c|c|c|c|c|c|}
\hline \multirow{2}{*}{$\begin{array}{c}\text { Isolate code } \\
\text { No. }\end{array}$} & \multicolumn{3}{|c|}{ Tested potato cultivar } & \multirow{2}{*}{ Mean } & \multirow{2}{*}{ Virulence* } \\
\cline { 2 - 4 } & Hermis & Mondial & Spunta & & \\
\hline ST 1 & 62.0 & 52.0 & 42.3 & $52.1^{\mathrm{p}}$ & M.V \\
\hline ST 2 & 66.0 & 55.0 & 44.6 & $55.2^{\mathrm{m}}$ & M.V \\
\hline ST 3 & 74.6 & 64.6 & 55.6 & $64.93^{\mathrm{h}}$ & M.V \\
\hline ST 4 & 91.0 & 78.0 & 68.0 & $79.0^{\mathrm{c}}$ & H.V \\
\hline ST 5 & 94.3 & 85.0 & 74.6 & $84.63^{\mathrm{a}}$ & H.V \\
\hline ST 6 & 81.0 & 72.3 & 62.0 & $71.76^{\mathrm{e}}$ & H.V \\
\hline ST 7 & 71.6 & 61.3 & 51.0 & $61.3^{\mathrm{j}}$ & M.V \\
\hline ST 8 & 64.0 & 54.3 & 44.3 & $54.2^{\mathrm{n}}$ & M.V \\
\hline ST 9 & 72.6 & 64.0 & 54.0 & $63.53^{\mathrm{i}}$ & M.V \\
\hline ST 10 & 65.0 & 55.3 & 45.5 & $55.26^{\mathrm{m}}$ & M.V \\
\hline ST 11 & 70.0 & 60.3 & 51.0 & $60.43^{\mathrm{k}}$ & M.V \\
\hline ST 12 & 81.0 & 68.6 & 58.3 & $69.3^{\mathrm{g}}$ & M.V \\
\hline ST 13 & 63.3 & 52.0 & 42.6 & $52.63^{\mathrm{o}}$ & M.V \\
\hline ST 14 & 91.0 & 79.6 & 69.6 & $80.06^{\mathrm{b}}$ & H.V \\
\hline ST 15 & 68.3 & 58.0 & 48.3 & $58.2^{\mathrm{l}}$ & M.V \\
\hline ST 16 & 60.0 & 50.0 & 40.0 & $50.0^{\mathrm{r}}$ & M.V \\
\hline ST 17 & 76.6 & 66.0 & 56.3 & $66.3^{\mathrm{f}}$ & M.V \\
\hline ST 18 & 61.0 & 51.0 & 41.0 & $51.0^{\mathrm{q}}$ & M.V \\
\hline ST 19 & 73.3 & 63.3 & 53.6 & $63.4^{\mathrm{i}}$ & M.V \\
\hline ST 20 & 88.0 & 75.0 & 64.6 & $75.86^{\mathrm{d}}$ & H.V \\
\hline Mean & $73.73{ }^{\mathrm{a}}$ & $63.28^{\mathrm{b}}$ & $53.37^{\mathrm{c}}$ & & \\
\hline S & 6 & & & \\
\hline
\end{tabular}

$* \mathrm{MV}=$ moderately virulent, i.e. scab index $<70 \%-\geq 50 \%$.

$\mathrm{HV}=$ highly virulent, i.e. scab index $\geq 70 \%$ of tuber surface.

- Each figure represents the mean of three replicates.

LSD for potato cultivars at $0.05=4.1$

LSD for Streptomyces scabies isolates at $0.05=1.1$

\section{Toxin studies}

3.1. Toxin production and quantification:

Thaxtomin A produced in the present study by the tested S. scabies isolates, i.e. ST5 and ST10 showed the same R $f$ as the standard Thaxtomin A used (Fig. 3). Spectrophotometer readings at 398, 395, $390 \mathrm{~nm}$ for standard Thaxtomin A and for extracted toxin of isolates ST5 and ST10, showed a similar spectral absorption curve for both standard toxin and the extracted toxin of both isolates. In addition, the eluted standard Thaxtomin A showed a single peak at retention time 20 min in HPLC determination. The extracted toxin of both isolates ST5 and ST 10 showed typically the same peak. Spectrophotometric curve used to quantify the toxin, showed that Streptomyces isolate ST5 produced the highest toxin concentration $(2.5 \mathrm{mg} / \mathrm{ml})$ on oatmeal broth medium while the isolate ST10 exhibited the lowest toxin production, i.e. $1.26 \mathrm{mg} / \mathrm{ml}$ medium (Fig. 3 and Table 3 ). 


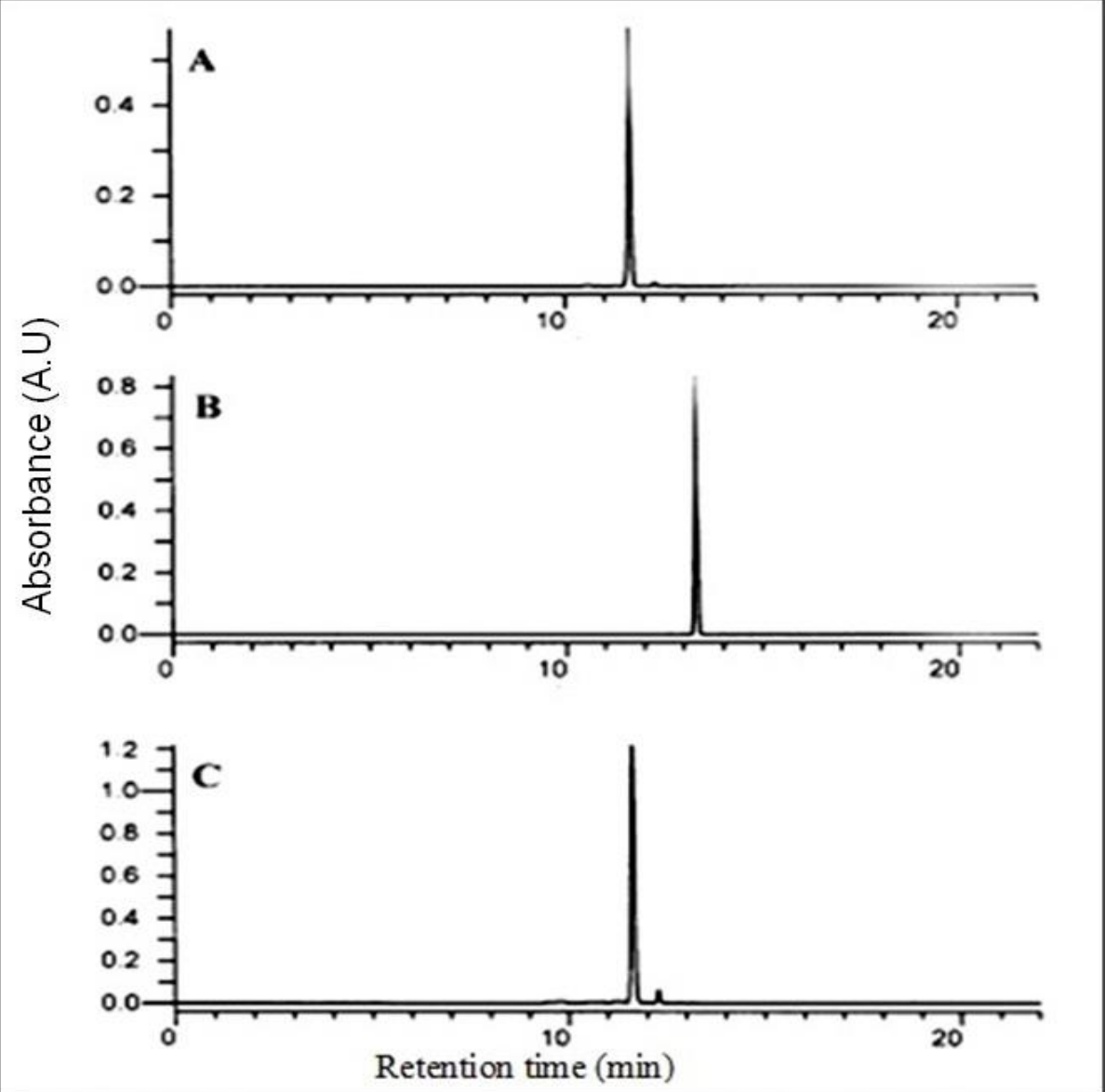

Fig. 3: HPLC chromatograms of standard Thaxtomin A (a), culture filtrate of S. scabies, isolate ST10 (b); and culture filtrate of S. scabies, isolate ST5 (c).

Table 3: Thaxtomin A production by the highly virulent and the moderately virulent isolates of Streptomyces scabies

\begin{tabular}{|c|l|c|}
\hline $\begin{array}{c}\text { Isolate code } \\
\text { No. }\end{array}$ & \multicolumn{1}{|c|}{ Virulence } & $\begin{array}{c}\text { Thaxtomin A production* } \\
\text { (mg/ml of oatmeal bran broth medium) }\end{array}$ \\
\hline ST 5 & Highly virulent & 2.50 \\
\hline ST 10 & Moderately virulent & 1.26 \\
\hline \multicolumn{2}{|c|}{ LSD at 0.05 } & 0.25 \\
\hline
\end{tabular}

* Thaxtomin A was measured, eight days after inoculation, in extract of (OMBB) medium.

- Each figure represents the mean of five replicates. 


\subsection{Duration and rate of toxin production by $S$. isolates:}

Data illustrated in Fig. (4) show that Thaxtomin A production increased with time up to eight days after inoculation with the tested isolate (ST5). Meantime, the maximum toxin production rate was occurred at 8 days and 10 days after medium inoculation with the tested $S$. scabies isolate (ST5).

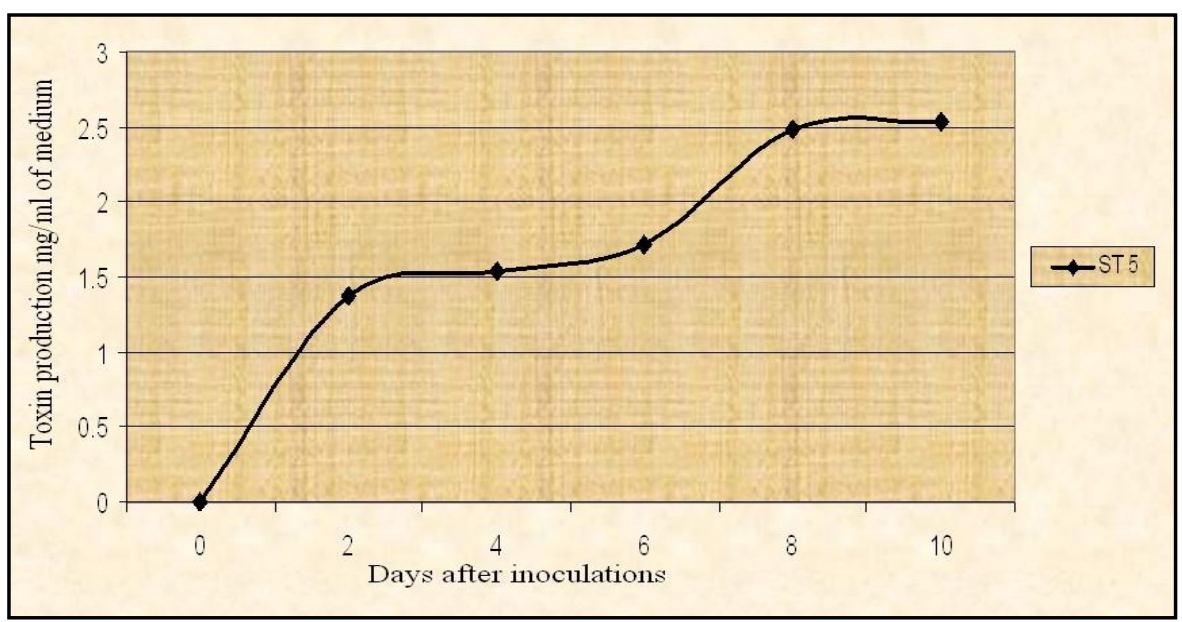

Fig. 4. Thaxtomin A production rate by Streptomyces scabies isolate (ST5) on oatmeal bran broth medium.

\subsection{The effect of temperature:}

Data presented in Table (4) and illustrated in Fig. 5 (a) show that the temperature of incubation of S. scabies, (isolate ST5), enhanced Thaxtomin A production of the isolate up to $28^{\circ} \mathrm{C}$ and recorded $1.88 \mathrm{mg} / \mathrm{ml}$ medium. However, the temperature of inoculation over this degree decreased the toxin production as recorded $0.92 \mathrm{mg} / \mathrm{ml}$ medium at $30^{\circ} \mathrm{C}$.

Table 4: The effect of temperature on Thaxtomin A production of Streptomyces scabies (isolate ST5).

\begin{tabular}{|c|c|c|}
\hline \multirow{2}{*}{$\begin{array}{c}\text { Temperature } \\
\left({ }^{\circ} \mathrm{C}\right)\end{array}$} & \multicolumn{2}{|c|}{ Thaxtomin A (mg/ml oatmeal broth medium)* } \\
\cline { 2 - 3 } & Inoculated medium & Uninoculated medium(control) \\
\hline 25 & 1.46 & 0.0 \\
\hline 28 & 1.88 & 0.0 \\
\hline 30 & 0.92 & 0.0 \\
\hline LSD at 0.05 & 0.40 & \multicolumn{2}{|c}{} \\
\hline
\end{tabular}

* Thaxtomin A was measured eight days after inoculation.

- Each figure represents the mean of five replicates. 

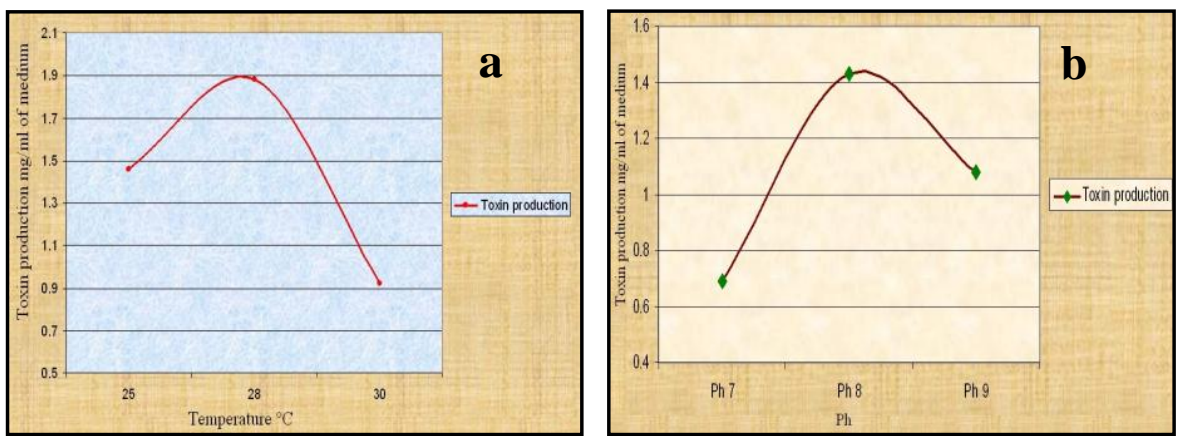

Fig. 5. Effect of temperature (a) and $\mathrm{pH}$ (b) on the in vitro Thaxtomin $\mathrm{A}$ production of Streptomyces scabies (isolate ST5) eight days after inoculation.

\subsection{The effect of $\mathrm{pH}$ :}

Data in Table (5) revealed that production of Thaxtomin A by $S$. scabies isolate ST5 was the highest at $\mathrm{pH} 8$ (Fig. 5b) as the toxin production was $1.43 \mathrm{mg} / \mathrm{ml}$ oatmeal bran broth medium. However, toxin production decreased at $\mathrm{pH} 7$ and $\mathrm{pH} 9$ where the toxin production was 0.69 and $1.08 \mathrm{mg} / \mathrm{ml}$ of oatmeal bran broth medium, respectively (Fig. 5b \& Table 5).

Table 5. The effect of $\mathrm{pH}$ on Thaxtomin A production of Streptomyces scabies (isolate ST5)

\begin{tabular}{|c|c|c|}
\hline \multirow{2}{*}{ Tested $\mathrm{pH}$} & \multicolumn{2}{|c|}{$\begin{array}{c}\text { Thaxtomin A production* } \\
(\mathrm{mg} / \mathrm{ml} \text { of oatmeal bran broth medium) }\end{array}$} \\
\cline { 2 - 3 } & Inoculated medium & Control ${ }^{*}$ \\
\hline 7 & 0.69 & 0.0 \\
\hline 8 & 1.43 & 0.0 \\
\hline 9 & 1.08 & 0.0 \\
\hline LSD at 0.05 & 0.25 & \\
\hline
\end{tabular}

* Thaxtomin A was evaluated 8 days after inoculation on oatmeal bran broth medium.

** Uninoculated oatmeal bran broth medium.

- Each figure represents the mean of five replicates.

\subsection{The effect of carbohydrates}

Data illustrated in Fig. (6) show that cellbiose applied to the tested OMBB medium enhanced Thaxtomin A production. Thaxtomin A increased with increasing cellbiose concentration and $3.57 \mathrm{mg} / \mathrm{ml}$ Thaxtomin A was recorded with $1 \%$ cellbiose. The fructose, however, decreased Thaxtomin A production to $0.1 \%$ fructose in the medium, while the higher fructose concentrations $(0.3-1 \%)$ exhibited a higher proportionate increase in toxin production. On the other hand, glucose application to OMBB medium inhibited the Thaxtomin A production at all concentrations tested, i.e. 0.1 to $1 \%$. 


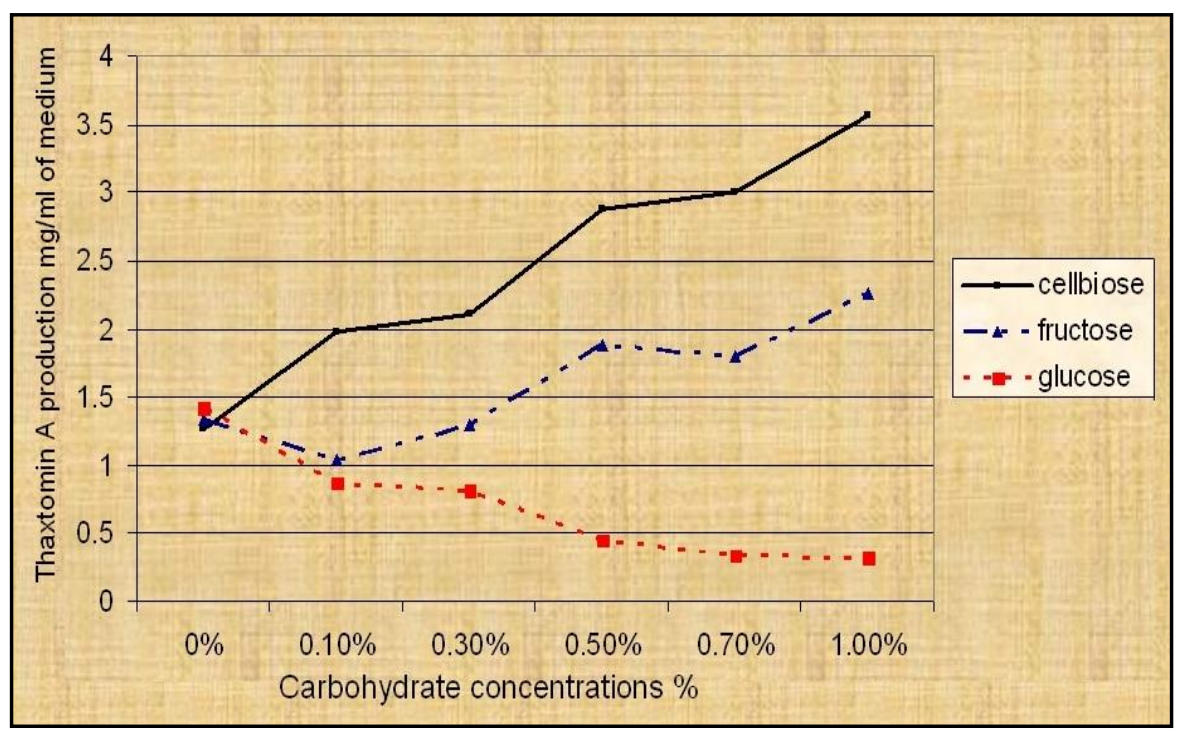

Fig. 6. The effect of carbohydrates in certain concentration on Thaxtomin A production of Streptomyces scabies isolate ST5 on oatmeal bran broth medium, eight days after inoculation.

\subsection{The effect of amino acids:}

Data in presented in Table (6) and illustrated in Fig. (7) show that the tested amino acids, i.e. tryptophan, phenylalanine and tyrosine applied to the OMBB medium inhibited Thaxtomin A production of the tested S. scabies, isolate ST5, in the medium. The tryptophan, however, exhibited the highest effect as toxin production in the medium was $0.39 \mathrm{mg} / \mathrm{ml}$ compared to $1.43 \mathrm{mg} / \mathrm{ml}$ for the unamended control. This was followed by phenylalanine and tyrosine as Thaxtomin A production was $0.63 \mathrm{mg} / \mathrm{ml}$ and $0.84 \mathrm{mg} / \mathrm{ml}$ for the two amino acids, respectively.

Table 6. Effect of certain amino acids on Thaxtomin A production of Streptomyces scabies isolate ST5 on oatmeal bran broth medium

\begin{tabular}{|l|c|}
\hline Tested amino acid* & $\begin{array}{c}\text { Thaxtomin A production** } \\
\text { (mg/ml oatmeal bran broth medium) }\end{array}$ \\
\hline Tryptophan & 0.39 \\
\hline Phenylalanine & 0.63 \\
\hline Tyrosine & 0.84 \\
\hline Control (unamended) & 1.43 \\
\hline LSD at 0.05 & 0.41 \\
\hline
\end{tabular}

* Amino acids were added as $2 \%(\mathrm{w} / \mathrm{v})$ of OMBB medium

** Thaxtomin A was measured 8 days after inoculation.

- Each figure represents the mean of five replicates. 


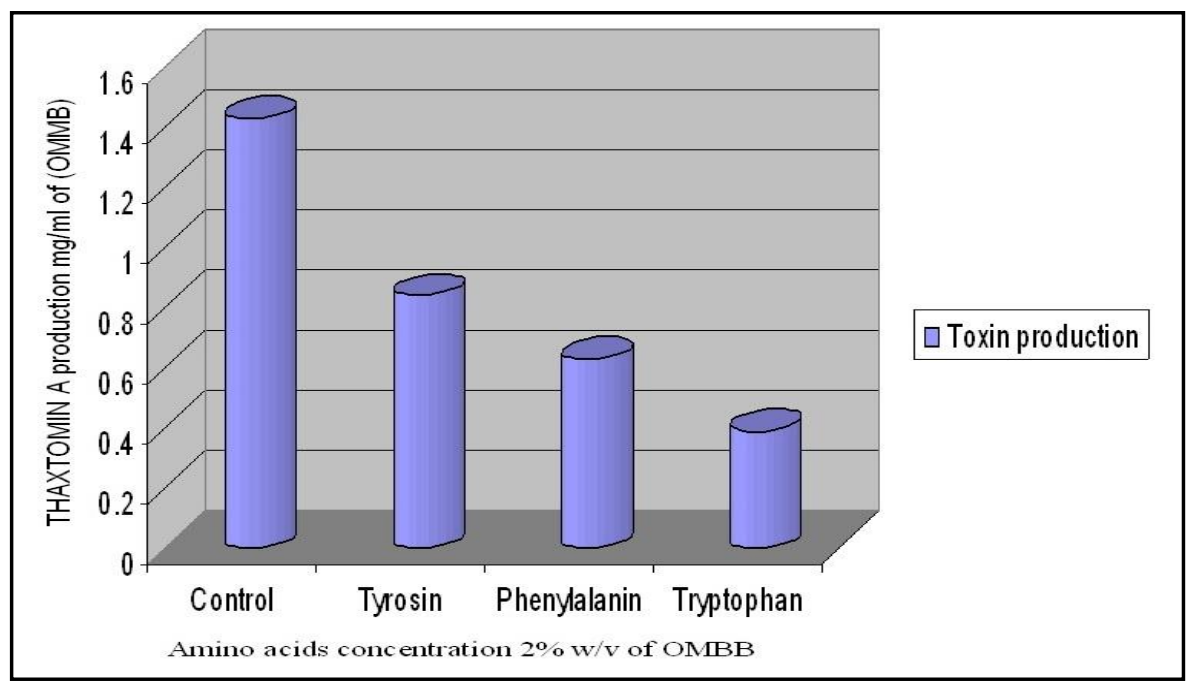

Fig. 7. Effect of certain amino acids on Thaxtomin A production of Streptomyces scabies isolate ST5 on oatmeal bran broth medium.

\section{D i s c u s sion}

All twenty Streptomyces scabies isolates recovered in the present study from Behera Governorate during 2009-2010 growing season were totally monomorphic for the morphological and biochemical characteristics investigated. All isolates were non motile, Gram positive, exhibited grey colonies, spiral spore chain and were melanin producers. Meantime the isolates showed positive reaction for catalase activity, starch hydrolysis, casein hydrolysis and gelatine liquefaction. Also, all isolates were tolerant to $\mathrm{NaCl} 5 \%, 6 \%$ and $7 \%$ and exhibited growth at $20,25,30{ }^{\circ} \mathrm{C}$ and $\mathrm{pH} 7$ and 9. None of the tested isolates could grow at $\mathrm{pH}$ 5. However, tested isolates differed in their virulence on potato mini tubers. Five isolates out of the twenty isolates investigated were highly virulent with scab $\geq 70 \%$. The other fifteen isolates were moderately virulent with scab index $<70 \%-\geq 50 \%$. Also, obtained results showed that the cv. Spunta was the most tolerant potato cultivar tested as exhibited 53.3\% scab index, while cvs. Mondial and Hermis were more susceptible and exhibited $63.2 \%$ and $73.7 \%$ scab indexes, respectively. Obtained results revealed an appositive correlation between the pathogenicity of $S$. scabies isolates and their ability to produce the phytotoxin Thaxtomin A. These results supported (Babcock et al., 1993 and El-Sheikh, 2010) view of the association of Thaxtomin A and S. scabies virulence. Plant pathogenic Streptomyces are known to synthesize Thaxtomin under two seemingly unrelated circumstances, in vivo within the periderm of infected potato tubers and in vitro on oat-based culture media. Presented data indicated that certain carbohydrate, i.e. cellbiose, glucose and fructose may influence Thaxtomin production. Potatoes are particularly high in starch, but starch 
does not support Thaxtomin A production. The sugar content of potato tubers can be as high as $10 \%$ of the dry weight (Kadam et al., 1991) and it has been reported that the incidence of potato scab is correlated with the level of reducing sugars, specifically glucose, in the tuber (Goto, 1985). However, appreciable Thaxtomin A production did not found on glucose, and when oatmeal broth is supplemented with glucose, Thaxtomin production is inhibited. These findings in particular are in agreement with Loria et al. (1995). Streptomycetes are capable of utilizing a wide variety of carbohydrates and other polymers not exploited by other soil microorganisms (Madigan et al., 2000 and Loria et al., 2003), due to a repertoire of highly regulated, secreted enzymes such as cellulases and xylanases that digest these large molecules into monomers and small oligomers, such as cellobiose, a product of cellulose degradation (Madigan et al., 2000). Streptomycetes are known to possess a cellobiose ABC-type transporter that brings external cellobiose inside the cell (Lopez Fernandez et al., 1995 and Antonopoulos et al., 2001) that in turn, stimulates the production and secretion of cellulases. Common scab infections are initiated on immature potato tubers in which the primary cell walls contain high levels of cellbiose. Presented results indicated that cellbiose supported Thaxtomin production, and when a potato tuber supplies this carbohydrate, the bacterium may respond by producing Thaxtomin A and ultimately disease symptoms. Oats, coincidentally, seem to contain an optimal combination, lacking in potatoes, that makes oat bran a superior medium for bacterial growth and Thaxtomin A production. Alternatively, Thaxtomin production and bacterial growth that result in host colonization may be not due solely to host-supplied signals, but might also depend on the soil environment. In the present study, no signals were found to support Thaxtomin production are unique to potatoes. Starch, glucans and xylans are common plant carbohydrates and are present in most roots and because Thaxtomin seem to target cellulose biosynthesis, one would expect plant pathogenic Streptomycetes to have broad host ranges. In fact, these organisms can infect underground structures of many crops, and are neither host nor tissue specific (Loria et al., 1997 and 2003).

Meantime, the present study confirms the regulatory effect of tryptophan on Thaxtomin A production in S. scabies isolates. These results in agreement with Babcock et al. (1993), who demonstrated that tryptophan, had a regulatory effect on Thaxtomin production in S. scabies and Thaxtomin A production was inhibited in all $S$. scabies isolates growing in the presence of $2.5 \mathrm{mM}$ of tryptophan. Secondary metabolism in actinomycetes is usually delayed or reduced by an excess of readily available nitrogen (Shapiro, 1989). It was observed that all amino acids caused a complete inhibition of Thaxtomin synthesis at a concentration tested in oat bran broth. However, the concentration of an amino acid necessary to cause an inhibition of Thaxtomin synthesis depends not only on the nature of the nitrogen source, but seems to vary among $S$. scabies isolates. The results also lent support to the hypothesis of King and Lawrence (1996) and King (1997), who suggested that Thaxtomin result from the condensation of $N$-methyl-4-nitrotryptophan and phenylalanine by diketopiperazine ring formation. Secondary metabolism in actinomycetes is essential to the survival of the bacteria in their natural environment. Regulation of secondary metabolism is modulated by a variety of factors so the organism can quickly adapt to its steadily changing environment (Shapiro, 1989). 
Thaxtomin biosynthesis is also regulated by several factors, such as developmental stage of the bacteria (Babcock et al., 1993), plant compounds (Beauséjour et al., 1999), glucose (Babcock et al., 1993 and Loria et al., 1995), and aromatic amino acids (Babcock et al., 1993).

\section{Refer e n e s}

Anonymous, 2000. SAS Users Guide. Ver. 8.1. SAS Inst., Cary, N.C.R.

Antonopoulos, V.T.; Hernandez, M.E.A.; Mavrakos, E. and Ball, A.S. 2001. The use of extracellular enzymes from Streptomyces albus ATCC 3005 for the bleaching of Eucalyptus kraft pulp. Appl. Microbe Biotechnol., 57: 92-97.

Archuleta, J.G. and Easton, G.D. 1981. The cause of deep-pitted scab of potatoes. Amer. Potato J., 58: 385-392.

Babcock, M.J.; Eckwall, E.C. and Schottel, J.L. 1993. Production and regulation of potato-scab inducing phytotoxins by Streptomyces scabies. J. General Microbiol., 139: 1579-1586.

Beauséjour, J.; Goycer, C.; Vachon, J. and Beaulieu, C. 1999. Production of Thaxtomin A by Streptomyces scabies strains in plant extract containing media. Can. J. Microbiol., 45: 764-768.

Bergy, D.H. 2004. Manual of Determinative Bacteriology. The Williams and Wilkins Company, Baltimore, CA, USA.

Delserone, L.M.; Loria, R. and Arias, I. 1991. Correlation between susceptibility of potato cultivars to Streptomyces scabies and sensitivity to Thaxtomin A. Phytopathology, 81: 1193-1200.

El-Sheikh, M.A. 2010. Common scab of potato as affected by soil mineral elements and tuber chemical constituents. J. Agric. \& Environ. Sci. Alex. Univ., 92: 1-24.

Faucher, E.; Savard, T. and Beaulieu, C. 1992. Characterisation of Actinomycetes isolated from common scab lesions on potato tubers. Can. J. Pl. Pathol., 14: 197-202.

Goto, K. 1985. The relationship between common scab severity and reducing sugar contents in the peel of potato tubers. Potato Res., 24: 171-176.

Healy, F.G.; Wach, M.; Krasnoff, S.B.; Gibson, D.M. and Loria, R. 2000. The txtAB genes of the plant pathogen Streptomyces acidiscabies encode a peptide synthesise required for phytotoxin Thaxtomin A production and pathogenicity. Mol. Microbiol., 38: 794-804.

Kadam, S.S.; Dhumal, S.S. and Jambhale, N.D. 1991. Structure, nutritional composition and quality. Pages: 9-35. In: Potato: Production, Processing, and Products. Salunkhe, D.K.; Kadam, S.S. and Jadhav, S.J. (eds.). CRC, Boca Raton. 
Kim, J.S.; Park, D.H.; Lim, C.K.; Choi, Y.C.; Hahm, Y.I. and Cho, W.D. 1998. Potato common scab caused by Streptomyces turgidiscabies. Kor. J. Pl. Pathol., 14: 551-554.

King, R.R. 1997. Synthesis of Thaxtomin C. Can. J. Chem., 75: 1172-1173.

King, R.R. and Calhoun, L.A. 2009. The Thaxtomin phytotoxins: Sources, synthesis, biosynthesis, biotransformation and biological activity. Phytochemistry, 70 (7): 833-841.

King, R.R. and Lawrence, C.H. 1996. Characterization of new Thaxtomin A analogues generated in vitro by Streptomyces scabies. J. Agric. Food Chem., 44: $1108-1110$

King, R.R.; Lawrenvce, C.H. and Calhoun, L.A. 1992. Chemistry of phytotoxins associated with Streptomyces scabies, the causal organism of potato common scab. J. Agric. Food Chem., 40: 834-837.

King, R.R.; Lawrence, C.H.; Clark, M.C. and Calhoun, L.A. 1989. Isolation and characterization of phytotoxins associated with Streptomyces scabies. J. Chem. Soc., 13: 849-850.

Lambert, D.H. and Loria, R. 1989. Streptomyces scabies sp. Rev. Inter. J. Sys. Bacteriol., 39: 387-392.

Lauzier, A.; Goyer, C.; Ruest, L.; Brzezinski, R.; Crawford, D.L. and Beaulieu, C. 2002. Effect of amino acids on Thaxtomin A biosynthesis by Streptomyces scabies. Can. J. Microbiol., 48: 359-364.

Lawerence, C.H.; Clark, M.C. and King, R.R. 1990. Introduction of common scab symptoms in aseptically cultured potato tubers by the vivotoxin, Thaxtomin. Phytopathology, 80: 606-608.

Leiner, R.H.; Fry, B.A.; Carling, D.E. and Loria, R. 1996. Probable involvement of Thaxtomin A in pathogenicity of Streptomyces scabies on seedlings. Phytopathology, 86: 709-713.

Lerat, S.; Marie, A.; Beaunoir, S. and Beaulieu, C. 2009. Involvement of the plant polymer suberin and the disaccharide cellobiose in triggering Thaxtomin a biosynthesis, a phytotoxin produced by the pathogenic agent Streptomyces scabies. J. Mol. Pl. Pathol., 10(5): 579-585.

Lopez Fernandez, C.L.; Rodreguez, J.; Soliveri, J.; Copa-Patioo, J.L. and PérezLeblic, M.I. and Arias, M.E. 1995. The effects of culture media on the production of xylan-degrading enzymes by Streptomyces chattanoogensis UAH 23. J. Basic Microbiol., 35: 405-412.

Loria, R. and Davis, J.R. 1989. Streptomyces scabies. Pages: 114-119. In: Laboratory Guide for Identification of Plant Pathogenic Bacteria. $2^{\text {nd }}$ Ed. Shaad, N.W. (ed.). APS press, St. Paul, CA, USA..

Loria, R.; Bukhalid, R.A.; Creath, R.A.; Leiner, R.H.; Olivier, M. and Steffens, J.C. 1995. Differential production of Thaxtomin by pathogenic Streptomyces species in vitro. Phytopathology, 85: 537-541. 
Loria, R.; Bukhalid, R.A.; Fry, B.A. and King, R.R. 1997. Plant pathogenicity in the genus Streptomyces. Plant Dis., 81: 836-846.

Loria, R.; Coombs, J.; Yoshida, M.; Kers, J.A. and Bukhalid, R.A. 2003. A paucity of bacterial root diseases: Streptomyces succeeds where others fail. Physiol. Mol. Pl. Pathol., 62: 65-72.

Madigan, M.T.; Martinko, J.M. and Parker, J. 2000. Brock Biology of Microorganisms. $9^{\text {th }}$ Ed. Prentice-Hall, Upper Saddle River.

Natsume, M.; Komiya, M.; Koyanagi, F.; Tashiroo, N.; Kawaide, H. and Abe, H. 2005. Phytotoxin produced by Streptomyces sp. causing potato russet scab in Japan. J. General Pl. Pathol., 71: 364-369.

Natsume, M.; Taki, M.; Tashiroo, N. and Abej, H. 2001. Phytotoxin production and aerial mycelium formation by Streptomyces scabies and $S$. acidiscabies in vitro. J. Gen. Pl. Pathol., 67: 299-302.

Shapiro, S. 1989. Nitrogen assimilation in actinomycetes and the influence of nitrogen nutrition on actinomycetes secondary metabolism. Pages: 135-211. In: Regulation of Secondary Metabolism in Actinomycetes. Shapiro, S. (ed.). CRC Press, Boca Raton, Fl., USA.

Shigeo, N.; Masayuki, M.; Shojit, T.; Daishiro, I.; Seishi, A. and Norio, K. 2006. Potato berry bioassay to detect Streptomyces spp. That produce phytotoxic Thaxtomin A and cause potato common scab. J. General. Pl. Pathol., 72: $135-142$.

Shirling, E.B. and Gottlieb, D. 1966. Methods for characterization of Streptomyces species. Int. J. Syst. Bacteriol., 16: 313-340.

Wach, M.J.; Krasnoff, S.B.; Loria, R. and Gibson, D.M. 2007. Effect of carbohydrates on the production of Thaxtomin A by Streptomyces acidiscabies. Arch. Microbiol., 188: 81-88.

(Received 11/09/2012; in revised form 15/10/2012) 


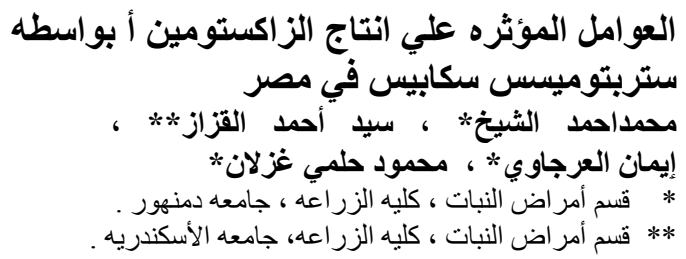

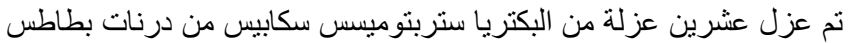

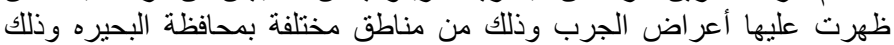

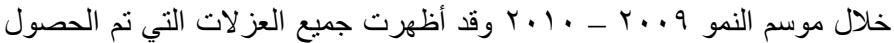

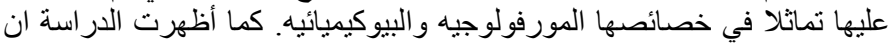

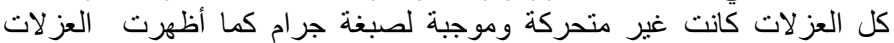

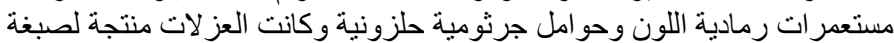

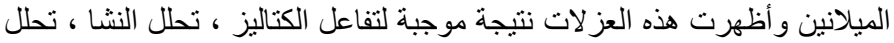

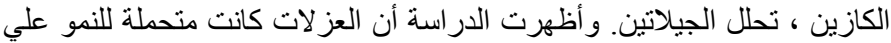

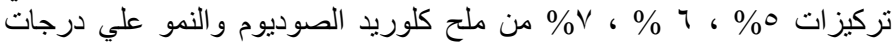

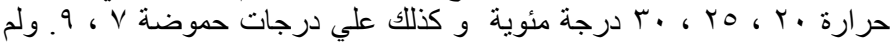

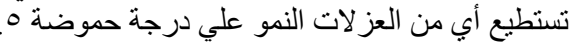

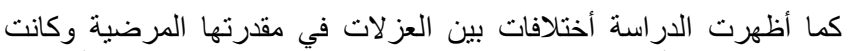

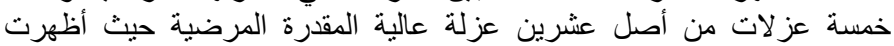

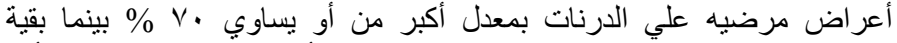

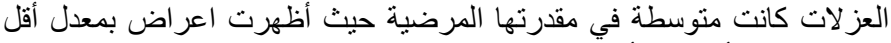

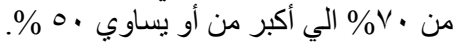

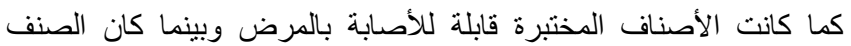

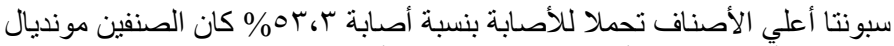

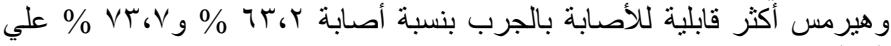
التو الي.

وقد أظهرت العزلة ST5 عالية المقدرة المرضية مقدرة كبيرة علي أنتاج

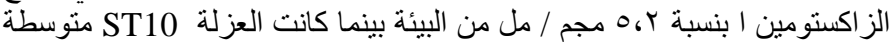

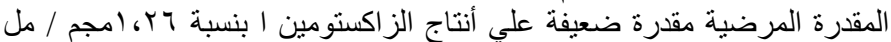

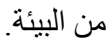

كما أظهرت النتائج أن افضل الظروف لأنتاج التوكسين هي ^^ درجة درجة مئوية ودرجة حموضة ^ وتركيز \\% من سكر السليبيوز .

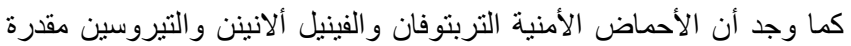

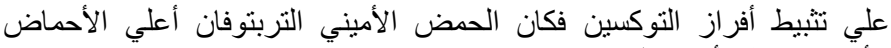
الأمينية تثبيطا لأفراز التوكسين. 